\title{
Singosaren As Interactive Space In Kotagede Tourism Destination
}

\author{
Irwin Panjaitan ${ }^{1, *}$, Moh. Prasetiyo ${ }^{2}$ \\ ${ }^{1}$ Magister student of Urban Design, Departement of Architecture; School of Architecture, Planning, and Policy Development, Institute \\ Technology Bandung, Indonesia \\ ${ }^{2}$ Lecturer, Departement of Architecture; School of Architecture, Planning, and Policy Development, Institute Technology Bandung, \\ Indonesia
}

\begin{abstract}
The development of the area for tourism purposes should have good sensitivity related to the product to consumption aspects, where the interaction between the local community is seen as the supply (insider) produce the products, which can then be consumed by the visitor as demand (outsider). Such sensitivity can be seen in the space between the private realm and the public sphere called the interface space. Development of the area for tourism, will enhance the touristsaccessibility in exploring its uniqueness as a tourist attraction. Accessible tourist attractions can improve the degree of permeability, which can also affect the degree of privacy of local communities. Singosaren as an area that will be designed as part of the united Kotagede tourist destinations, Yogyakarta, should consider the influence of tourism activities on a daily basis of the community. Permeability study in the area with mapping method, is expected to connect local potency to the circulation pattern in the interface, by finding the street corridor that needs to be anticipated, to maintain the sustainability of tourism activities in Singosaren area.
\end{abstract}

Keywords: Permeability, interface, tourism destination, socio-culture

\section{Intoduction}

The tourism development as industry has the ability to encourage economic improvement for the surrounding community. Economic enhancement happens when the job opportunity available for the community, through the ability that can be a selling point. Yogyakarta with a large degree of Natural and Cultural diversity, potential to continue to be developed with a variety of alternative tourism destinations.

Tourism basically offers a unique experience, different from the daily life of the visitor. Kotagede as one of the alternative tourist destinations in Yogyakarta, has a very dense circulation intensity, which is not comfortable for tourists. Density occurs because the street dimension is not proportional to the high circulation intensity. Convenience achievement for travelers is the most important part of tourism, when one's experience of exploring an area will be influenced by what a visitor can access from his/her path (Dovey, 2016: 187). Visitor's space experience will provide a complete picture of the image of the area.

Singosaren located between Kotagede as tourist destinations and the Ringroad corridor of Yogyakarta as the primary arterial road. There is opportunity in Singosaren area to develop a new tourism access to the Kotagede tourist destination. The sustainability of Singosaren area development as a unity of Kotagede tourist destination is influenced by Howe the interaction of the inhabitants as the supply and the outsider as demand is formed. This paper attempt to identify the influence of the new tourism access development in the Singosaren area.

\section{Methods}

Data collection method is done by doing direct observation such as recording using camera, taking notes, and also sketching in the study area.

Informal interviews also conducted to some locals and tourists to get information related to daily activities on the area and the tourism activities.

Qualitative descriptive analysis method used to describe a certain character in a systematic, actual, and accurately. (Ariknto, 1998). The paper attempts to explain the relationship between theory and the existing conditions found in the study area. Mapping technique is used to facilitate the understanding of the relationship of activity patterns on space.

\section{Understanding The Permeability study}

Moughtin (2003) attempted to map The Townscape analysis by Cullen (1966) into three parts: perceptual structure by prioritizing the legibility of urban structures, how easily a user accepts, understands, and responds the environment; Permeability study talks about the degree

Corresponding author: irwinsmart23@gmail.com 
of choice that users have when doing a movement within the area; and Visual study is how a user can recognize the area uniqueness that can be the meaning of a place. Urban design studies specialized in public sphere as its study area, and attempt to accommodate both private and public needs simultaneously. Carr (1992) explained that urban design should be able to realize three main values as a determinant quality in public space, such as responsive, democratic, and meaningful.

Urban design is strongly influenced by the movement that can connect the activities in the area (urban connectivity) by dividing the area into blocks of building mass and open space for circulation needs, which then form the structure of the spaces in the area (Lynch, 1960; Carmona, 2010; Dovey, 2016). In designing tourism area, providing a unique experience that visitors are looking for will depends on how the area is formed (product for consumption). Making the area as a product for tourism consumption means being able to bring together the expectation of the visitors with the experience received in the area. Tourism activities as an industry is the most effective way of learning a new and old area (Dovey, 2016: 185). There is a clear distinction of seeing tourism from the perspective of the residents (insiders) and visitors (outsider), where the visitors should be able to capture the image through the area morphology.

- The text should be set to single line spacing.

- Paragraphs should be justified.

- The first paragraph after a section or subsection should not be indented; subsequent paragraphs should be indented by $5 \mathrm{~mm}$.

The use of sections to divide the text of the paper is optional and left as a decision for the author. Where the author wishes to divide the paper into sections the formatting shown in Table 2 should be used.

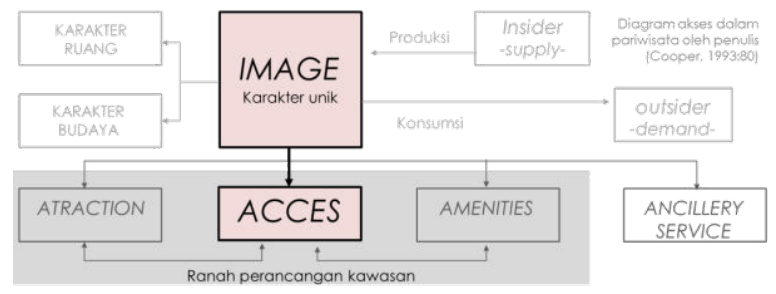

Fig. 1. The Relationship Between Access and Tourism Destination Image.

Dovey (2016) explained that flows of pedestrian traffic together with the traffic ideas, identities, images, $\&$ products, are at the heart of what makes cities urban, in what ways do they enable and constrain urban connectivity. The design of Singosaren area as part of Kotagede tourism destination will try to increase circulation intensity to the tourism attraction in the area. This improvement will shown in the connected corridors(streets), where the visitors movement can make a space experience, then form an image of the area that can be accepted by visitors.

Moughtin (2003) explained that the design of the interface between the public realm and the more private areas of individual properties is a legitimate concern of urban space. The statement strengthen the needs of designer's sensitivity in responding to the presence of visitors in the Singosaren, which will greatly affect the space between the private and public sphere (interface spaces), when visitors have the ability to access the formed streets. There is a clear connection between the degree of accessibility to privacy, where access leads the freedom of visitors to move, and privacy leads to the sense of security that residents require.

Bentley et al (1985) stated that both physical and visual permeability depends on how the network of public space divides the environmental into blocks area: areas of land entirely surrounded by public routes. The statement explain that the degree of permeability has a strong relationship between the street layout and the building blocks formed on the area structure. The higher the accessibility of the area, the privacy of the occupants will decrease, and vice versa. The Singosaren area sustainability as a tourist area is determined by how the designer's sensitivity sees the influence of tourist circulation in accessing the area, especially interface space. Mapping technique and direct observation (photo recording and skecthing) were being used to identify the permeability in the area.

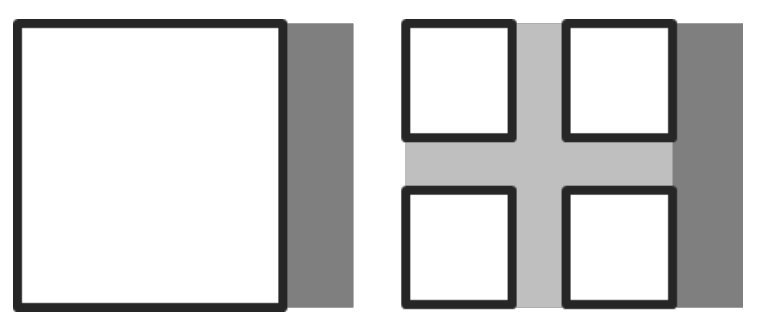

Fig. 2. Diagram of Relationship Between the Increasing Access and Permeability on the Same Spatial Scope.

\section{Typology of interface space}

The quality of the interface space formed in the private sphere and the public sphere can determine the life activity that occurs in the street space as a circulation. Jacobs (1961, 39) tried to promote the slogan 'eyes on the street' as a benchmark in assessing the contribution of the interface space to the user's sense of security, as well as the interactions that occur in the space. Gehl classified public/private interface morphology as a long series between 'soft'/active' that are social and permeable and the 'hard'passive' that are antisocial and impermeable, which both contradicted. This classification is based on social interaction. The influenced factors are transparency, activity, diversity, design quality, and building dimensions (Dovey, 2015).

Typology of interface space is made to facilitate the designer in designing a livable and attractive street. Dovey \& Wood then developed a more detailed public/private interface typology, with criteria including: permeability, related to the pedestrians ability to access the interface space; transparency, related to the media in interface space that limits the public gaze into private space; setback, the distance between the private and public spaces in the private sphere, which makes it publicly accessible; Car dependency, the object that 
dominates access to the building facade (interface) by people or vehicles. (Dovey 2016, 59).

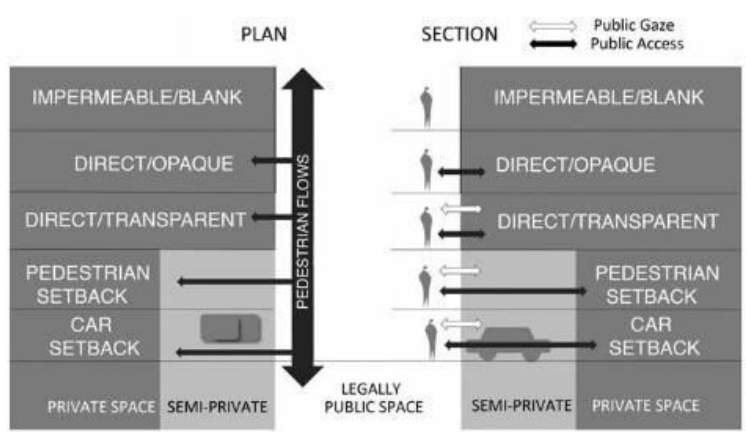

Fig. 3. Interface Tipology.

Source: Dovey \& Wood, 2015.

These variables form the basis of an interface typology consisting of 5 types (Dovey, 2016): impermeable / blank (type A), direct / opaque (type B), direct / transparent (type C), pedestrian setback (type D) and car setback (type E).

Type $\mathrm{A}$ is an interface space in a building that does not allow spatial and visual access. This model is usually appears as building walls or fences without access, directly adjacent to the street, which is often used as billboards or street art.

Type $\mathrm{B}$ is a building interface space adjacent to the street space, allowing pedestrian access into the private space within the building directly, but does not provide visual access because no openings or the walls are less transparent. This type appears as building wall with door access, has a large window openings, or an accessible building fence, usually seen in apartment buildings, offices, etc.
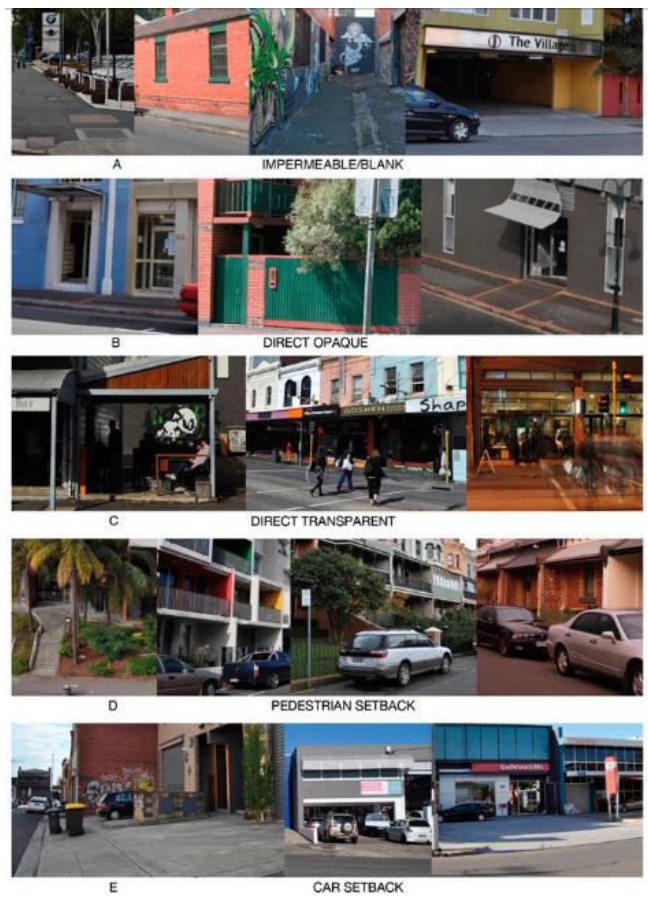

Fig. 4. The Examples of Interface Tipology Source: Dovey \& Wood, 2015.
Type $\mathrm{C}$ is an interface space in buildings that allows pedestrian and visual access. The building walls or fences are dominated by openings. This type can generally be found in commercial buildings, and there's possibility of this typeto be adapted into other functions.

Type $\mathrm{D}$ is an interface space in the private realm with buildings that have a setback between private buildings and public street spaces, as semi-private spaces. Building walls or fences can be directly accessed spatially and visually, without any obstacles.

Type $\mathrm{E}$ is an interface space that has a similarity to type D. The difference is the presence of interference or obstacles in the semi-private space to be accessed spatially and visually. The interface space is often used as parking area for vehicles.

The diversity of these typologies can indicate the relationship between interface space's function alteration with the degree of circulation intensity within the space. Singosaren area planning as part of Kotagede tourism destination, needs to consider the possible level of change in the space of its interface

\section{The Description of Singosaren Area}

To study the Singosaren spatial pattern, it is necessary to describe the relationship of the surrounding area. Singosaren area is located between the center of the tourist destination Kotagede, and South Ring Road of Yogyakarta. The opportunity to open new tourist access that can connect the southern ring road of Yogyakarta to the center of tourist destination Kotagede is discovered, which is passing the Singosaren area. The new access will have an influence on the development of Singosaren area, so the arrangement of Singosaren Area needs to be done carefully to support the creation of he united Kotagede tourist destination.

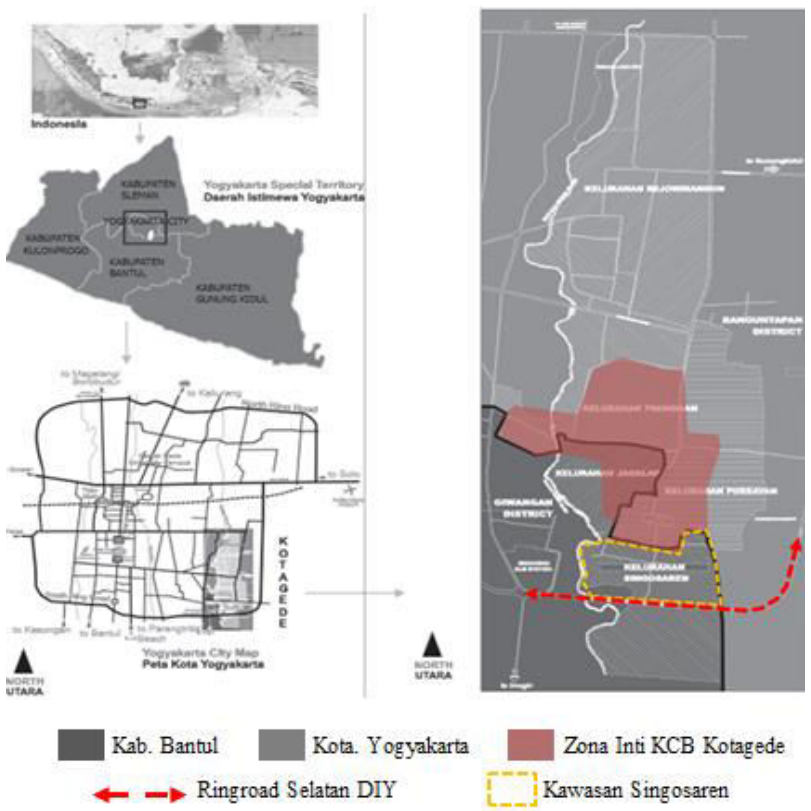

Fig. 5. Singosaren in Yogyakarta.

Source: Remade by Panjaitan, 2017, from Kotagede Pusaka Area, JRF, 2007. 
The Singosaren area as a designed area has territorial boundaries, such as: the north side by the administrative boundaries of Jagalan and Purbayan districts; the southern side by the southern ring road of Yogyakarta; the west side by the Gajahwong River; and the eastern side by the Purbayan street.

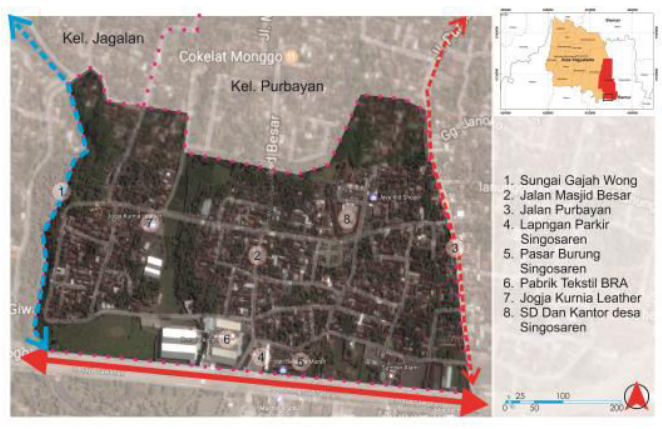

Fig. 6. Designed Area Boundaries.

To facilitate the understanding of the Singosaren area exsisting conditions, the pilot study is done based on the urban design elements, adapted to the movement within the area. The urban design elements by Shirvani (1985) can be adapted to the needs of the designed area context, which is the need for interaction between visitors and occupants in the interface space along the space of movement/circulation. The design elements used in this permeability study are: space utilization (landuse \& activity support), to see the relation of spatial function influence the movement within the area; Circulation and parking, to see the relationship between street classification, transportation modes and the placement of parking nodes within the area; building masses arragement (Building form and massing), as the forming scope of street spaces which can encourage interaction; Open space, intervened space for tourism activities.

\section{Function Of Space}

there are several functions in the Singosaren that can affect the movement within the area. Based on the observation, the existing textile factory as industrial function at the main gate of Singosaren, has the greatest influence. Large factory have many employees, increasing the neccesity of residential function for the workers who are dominantly come from outside the area, impacted in exsisting residential houses turned into a boarding house. In addition, Singosaren parking lot, empty buildings, and open spaces surround the factory utilized by the local community as a parking lot for employees.

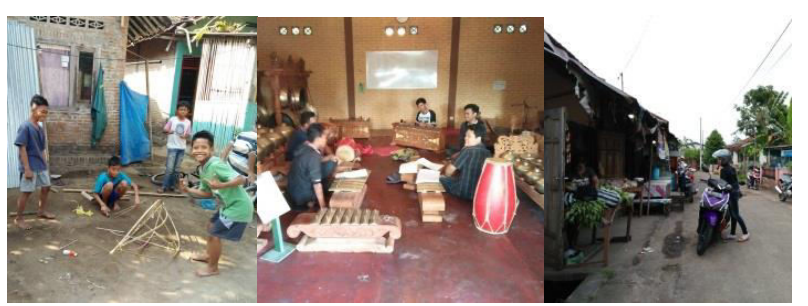

Fig. 7. Example of Space Utilization in the Area.
Some functions can be the driving forces in the Singosaren, such as: three mosques in the area, two clinics, the presence of elementary school, and district office in the designed area. The presence of car parking for Kotagede tourist in the Singosaren region, generating supported activities such as kiosks and the afternoon market, to meet the tourists needs. The building functions along the collector road class become a commercial activities. Dominant functions of the existing commercial use come in food stalls, grocery kiosks, salons, and some textile and invitation cards production offices. There are also several functions of the home industry like traditional culinary 'yangko', puppet handicraft, and silver handicraft. Some leather craftsmen also exist as wholesalers and warehouses.

In addition, in the area are found some unique cultural activities, such as the discovery of leather puppets craftsmen, and silver craftsmen, who work on their homes on the basis by orders. The center for art training activities for various art communities in the area Singosaren were found, on Singosaren art studio building. Lastly, there area also found the existence of pigeon lovers community activities in the open space of rice fields.

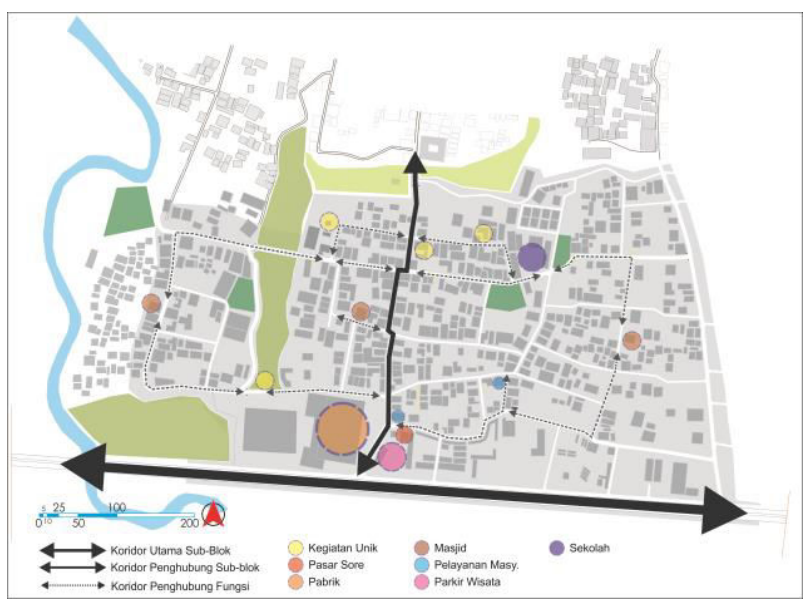

Fig. 8. Mapping of Space Utilization on Singosaren.

\section{Circulation and parking}

The movement in the Singosaren Area is centered on the Singosaren corridor from the center of Kotagede to the southern Ringroad of Yogyakarta. Thick and thin lines on the map illustrate the dimensions of the road in the Singosaren area. The existing road hierarchy is formed based on the road width. To reach the Singosaren whole area can be done by walk because it is within a 500 meters (walking distance). The street dimensions are diversed and mainly have two directions, often causing traffic jam. The singosaren corridor is also used by locals as the main route to reach the functions within the area. The intensity of two-wheeled and fourwheeled vehicles dominates the area circulation, while the pedestrians intensity is very low, and the area is unreachable by public transport such as buses. 

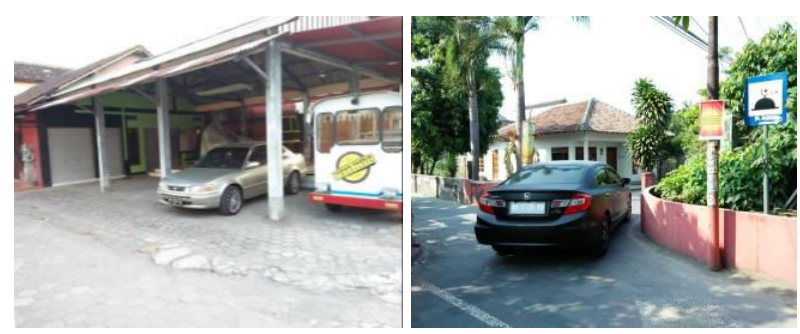

Fig. 9. Example of Circulation and Parking in the Area.

The limitations of street space in the area, making some houses within the area cannot be accessed by four-wheeled vehicles, and not allow for on-street parking. The available parking area in Singosaren usually use the open space in private plots located right on the side of the road, used as shared vehicle parking.

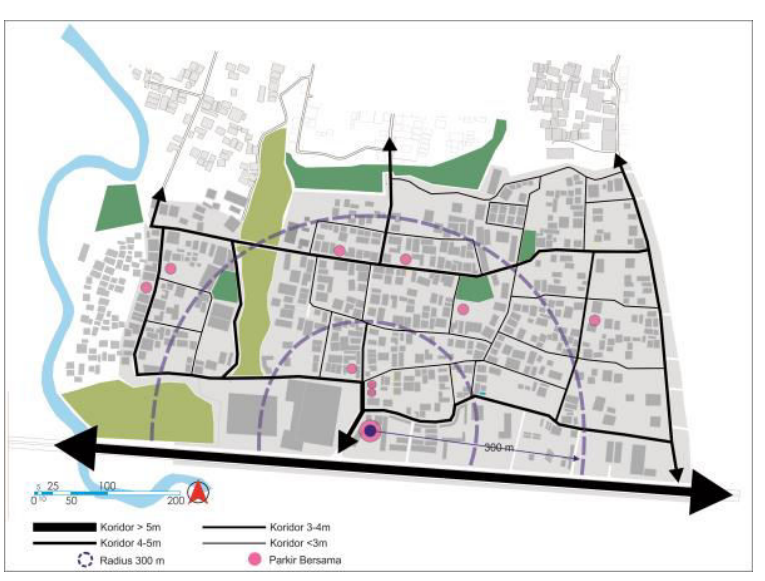

Fig. 10. Circulation and Parking Area Map in Singosaren.

\section{Building Layout}

In general, the buildings are dominated by one-floor residence, with a neo-vernacular style from the strong Javanese character with sloping roof. Some buildings are not maintained because it's not vacant, and the other reason is because the building is still semi-permanent. The buildings are oriented facing the main road as access to enter the building. Space in buildings adjacent to roads often turns into commercial activities. Meanwhile, the increasing occupancy needs in the area, making some buildings increase the intensity.

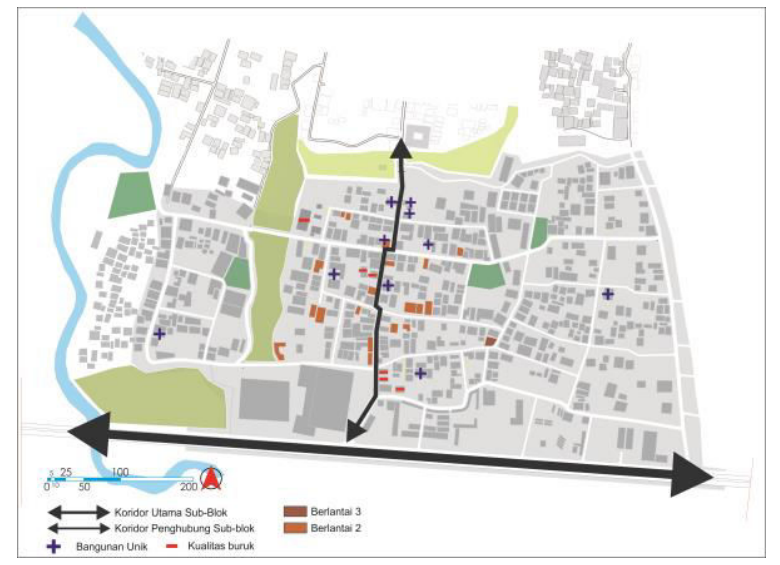

Fig. 11 Building Quality Mapping in Singosaren.
The existing building mass in the designed area, especially the residential area, generally consists of 1-2 floors buildings where the dominant building sizes are 50-200 square meters. Residential are generally has a private open space on the front or rear, there are even some who have setbacks on four sides.

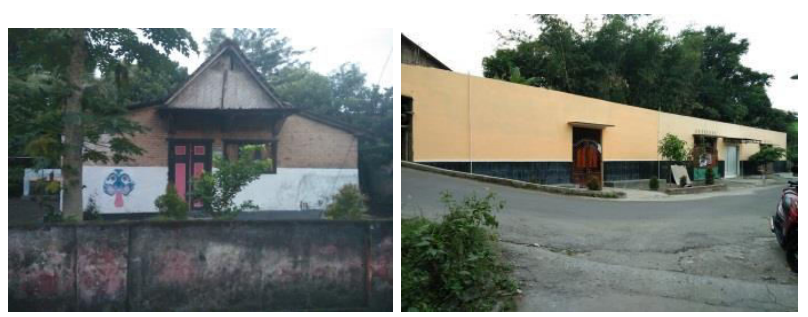

Fig. 12. Example of Building Quality in the Area.

The fence as element in the area acted just as a barrier between private space and public space. Fences in general have a height that can still be accessed at the height of the human eye, which can be accessed visually. Some buildings with function as boarding houses with modern style, have a high fence and formed in more massive and solid built. Modern boarding house buildings have minimalist style with less Javanese character, either in shape or its building facade.

\section{Open space}

In the area, no open spaces are planned for social community activities. Lots of open space in private plots were found and often used as social space of the community. The open space were used for interaction space, children playground, community meetings, shared parking, etc. Also, visitors were allowed to access private land for public access, utilizing the setback space on the fence.

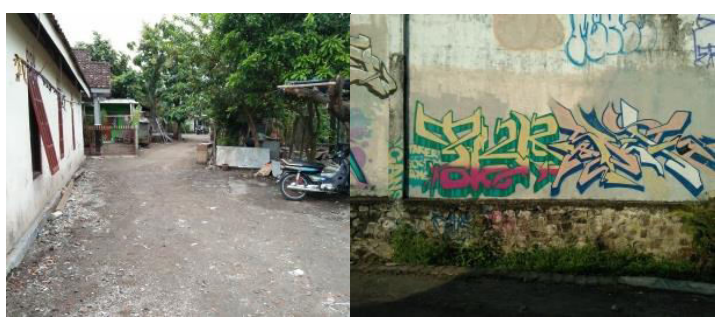

Fig. 13. Example of Open Space in the Area.

Open space such as streets and courts, formed by building fence or directly adjoining by building wall. The dimension difference between street width and the building height is 1:1 ratio, so the formed space is very strong. Some parts of open spaces that do not have a building facade, serve as a creative medium for mural activity. Some open space also has special functions such as rice fields and cemetery. 


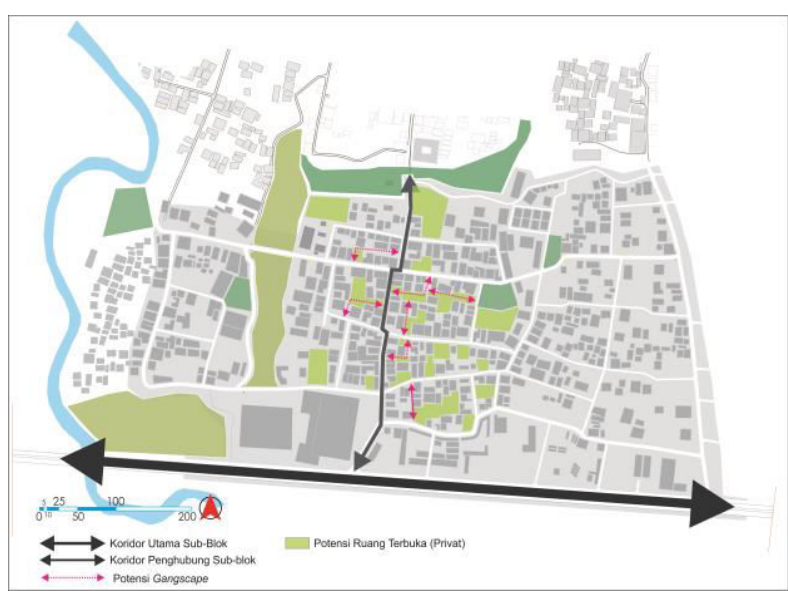

Fig. 14. Mapping of Open Space on Singosaren.

\section{Interface on the Singosaren area}

Singosaren region has a variety of interface conditions. In general, the function of buildings in the area are residential and commercial functions, with main entrance is oriented to the road. Very limited street space dimensions with an average width of two to five meters, making public visual access (public gaze) easy to reach space in communityowned buildings. This condition does not interfere with the privacy of the community because the community has strong social ties so that frequent interactions between local communities occur in the interface space. Here are some interface types found in the Singosaren region:

\section{Impermeable/ blank Interface}

Generally found in buildings located at crossroads without visual and spatial access. The orientation of access leads to the main road, making the other side of the building has a wall without the facade. In addition, some case happen to avoid unexpected views such as funerals. The sides of the building without setback have the lowest class streets, some of them are decorated with street art, and the interaction considered minimal. This condition is not related to the function of the building.
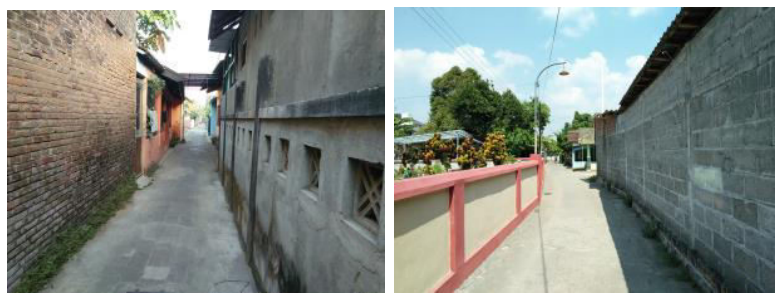

Fig. 15. Example of Impermeable/ Blank Interface in the Area.

\section{Direct / Opaque Interface}

The building has no setback on the road, which can only be accessed spatially. Those generally are found in buildings with boarding house function or commercial like kiosk. Interaction occurs on the street space which facing the entrance access of the building. The distribution of this interface is influenced by building functions and the limitation of building lot in the area.
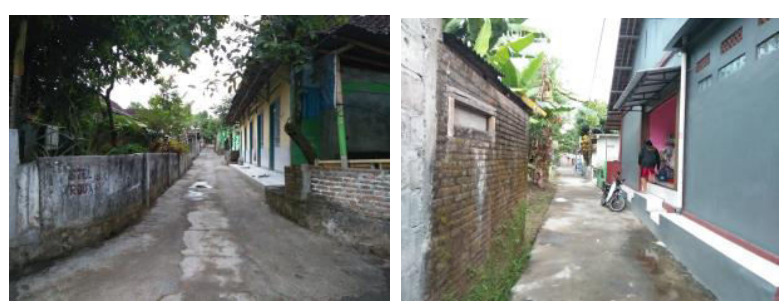

Fig. 16. Example of Direct/Opaque Interface in the Area.

\section{Direct / Transparant Interface}

This Interface space is commonly found in the public buildings and commercial buildings in the area. The openings have dominated the walls of buildings. The interaction in this typical interface space is very high, due to the easy visual and spatial access from the street space into the building space. This model is often found in high circulation intensity street.
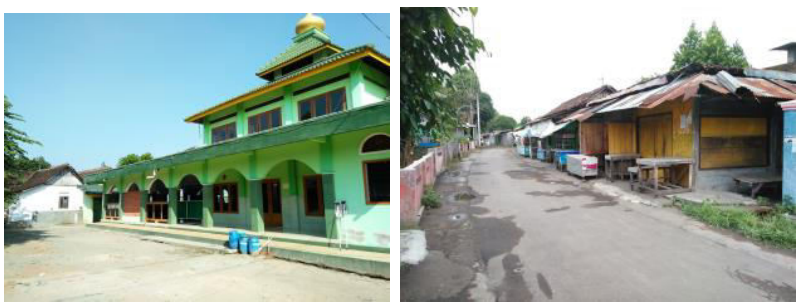

Fig. 17. Example of Direct/Transparent Interface in the Area.

\section{Pedestrian Setback Interface}

Buildings with setback are found in buildings with residential functions. The barrier as element between private plot boundary and public street space formed as wall fence. Fences, in general, have a good transparency, a lot of house fence that is not solid or discontinuous, easily accessed spatially. This can indicate the strong social interaction of the local community in the interface space.
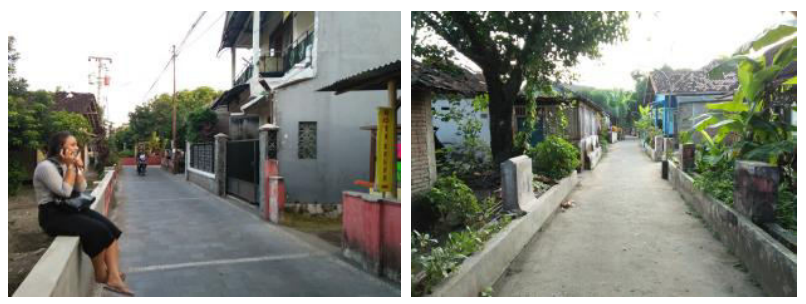

Fig. 18. Example of Pedestrian Setbak in the Area.

\section{Vehicle Setback Interface}

Having a setback that is not much different from the typical pedestrian setback, the difference is the discovery of obstacles in public space when accessing visually or spatially to the private space within the building. Generally, the disturbance is caused by the use of parking vehicles, and also some because of the trees. The interaction between residents and visitors is very low. Some types of these interfaces occur in buildings that are already uninhabited, and which has a fairly wide setback. 

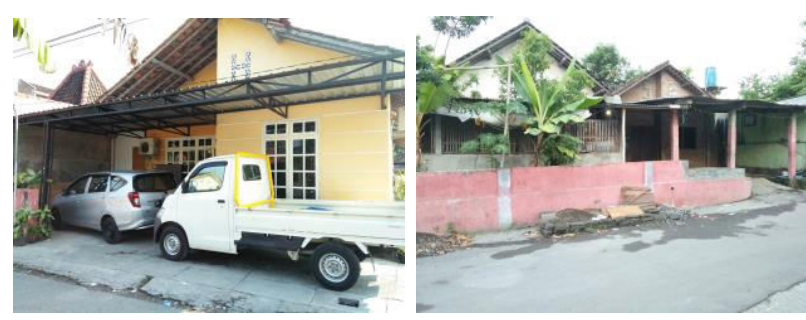

Fig. 19. Example of Vehicle Setback Interface in the Area.

\section{Design Guidelines}

From the observations made in the designed area, has found some potency and problems that can be used as a guidelines in the designing Singosaren area as part of Kotagede tourist destinations.

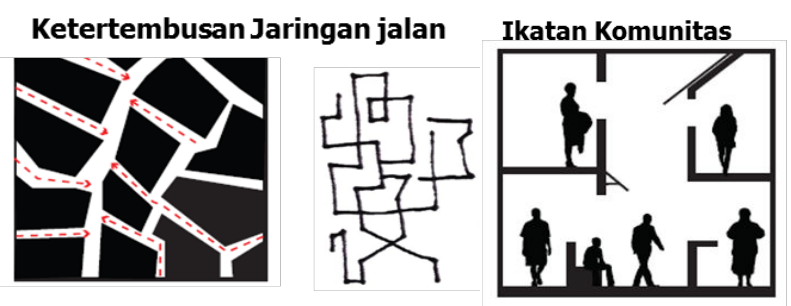

Fig. 20. Output Sketch in the Area.

\section{Problem}

The building style in the Singosaren area generally has no conformity to the typical character of Kotagede with the typology of Javanese buildings, where the building has a roof slope. Building function change into a boarding house and commercial, impacted to a new modern style building with a flat roof.

The unstructured pedestrian path quality, which does not have clear articulation according to the mode of transportation it carries. The material used has not been able to provide direction of movement and the movement speed of the users.

The incompatibility of the quality of the visual range between the spatial scale to the speed of movement, affecting the ability to memorize of the users.

Lack of open space quality for social activities, which does not support the diversity of Singosaren community cultural activities especially to support tourism activities.

\section{Potential}

Strong community social interaction in conducting activities together, also in daily life, can be seen through the building elements on the interface space, which allows interaction.

Utilization of private space for the public in the area can show the level of flexibility of the community to adapt to the new things they receives

Potential diverse cultural activities for tourist attraction in the Singosaren, used as circulation orientation, to show the possibility of appropriate building functions changes along the street.

Area ranges within a pedestrian radius $(500 \mathrm{~m})$, can be used as a pedestrian priority area, encourage tourists to explore the area freely and discover a variety of uniqueness within.

From the potential and the problems, the design guidelines try to be compiled based on the elements of the design of the area, which connects the enhancement in the movement circulation to the degree of permeability of the area. The discussion focuses on the interface space along the road in the Singosaren area as part of the Kotagede tourist destination.

\section{Function of space}

In general, the land use in the Singosaren does not need to undergo significant changes, remaining as medium-density dwelling areas. Guidelines for functional change should be made in some street corridors for tourists circulation as a planned pedestrian priority. Changes in the function need to be done on the space within the building that is bounded directly on the public road. The function of the space is a semi-private function. In residential buildings, the appropriate functions are living room, family room, etc. Changes in semiprivate rooms may also be directed for commercial functionss. On street corridors that accommodate the circulation of motor vehicles, building functions can be directed to commercial functions become commercial corridors. The road setback that lies along the commercial corridor does not use fences, encourages continuity of movement and allows for parking space activities.

In addition, street setback can also be used for supporting activities that can improve the social life interaction of the community such as guard posts, or encourage economic activities such as 'angkringan' (hawker), as well as place for road amenities. Changes in building functions that can be accessed directly from the main corridor of Singosaren, especially in the corridor with alley typology, can be directed to accommodate the tourists with guest house building typology.

\section{Circulation and parking}

The main parking area is in Singosaren square, often used by the community as a space for entertainment activities at night or non holiday season, and also for tourist's parking to Kotagede. The land use needs to be re-design, especially the parking lot layout, to optimized the functions as green open space which can also be utilized as a space of social activity (multiuse space). The parking spots are also directed transit spaces with varied modes for tourists, which are still accessible to the attractions within the area.

Some of the corridor's circulation within the Singosaren area are still within a pedestrian distance radius, and others for vehicle circulation, should be supported by the use of materials, textures, colors that can clarify the articulations according to the movement modes. The main corridors connecting the southern ring roads of Yogyakarta and the Kotagede destination are prioritized for pedestrians, while circulation by vehicles circles the periphery of the area. This intends to support the equity of circulation within the Singosaren region.

To ensure the safety of each mode of transport between the pedestrian and the vehicle, it is necessary to maintain the 
speed of movement within the area with traffic calming, especially on the nodes of pedestrian encounters and riders. Traffic calming can be done with different color, texture, bumper and also strengthening the fence with the height of the human eye at the corner meeting.

\section{Building Layout}

The intimate scale of the road space has been formed on the comparison of road space and ground floor of the building. An intimate scale needs to be guarded by directing a rooftiled building, and also adjusting the height of the building such as adding a floor of a building on the ground floor should use a podium system. To support tourism activities, building facades should be designed to allow for interaction between visitors and residents. The design can be done by placing openings on the walls of the building facing to public access.

The degree of transparency on the walls of the building adjusts the degree of privacy of space functions, and the setback on the side of the road corridor should not be used for permanent parking. Fences became the most typical element of the current Singosaren region. In the fact, the fence is only a barrier element between plots, which is also used as a barrier element between private and public space. To support tourism activities, fencing in commercial building functions needs to be eliminated in order to increase spatial continuity. While in the building of residential function, the fence elements need to be strengthened so as not easily accessed spatially, while maintaining wall transparency or according to the height of the human eye.

\section{Open space}

Creating an open space for public activities and as a space of interaction between visitors and residents, can make varietes of attractive activities. The high level of community flexibility can be utilized by plotting private plots that are not used as a space of public activity, becoming a tourist attraction in thearea. Potential utilization of connected open space on private plots become new publicly accessible corridors.

The corridor between private plots can be a typical street with the concept of the alley, which connects visitors to the attractions in the area. The typical corridors of the selected alley are those that have a direct spatial connection to the main corridor of Singosaren. In addition, to increase the quality of pedestrian comfort during interaction or activity, open space along the road corridor in the form of setback plot, can be done by adding the number of trees along the Singosaren corridor.

\section{Conclusion}

The movement pattern has an important role in conducting the design of the area as a tourist area. The local potency used as a tourist attraction, can stimulate the connection through new access. Growing more access will further increase the permeability of the area, which can indirectly decrease the privacy of the residents. The design of the interface space is important, in order to support the interaction space between the visitor (outsider) and the inhabitant (insider), where the occupants remain their privacy and still increase the route options for visitors. The new access that is formed is influenced by the placement of tourist attraction nodes and the existence of open space that allows design intervention.

In exsisting area are found that strong factors affect the quality of the interface space as interaction space, just as what Dovey had found: Permeability in the area is formed due to the tourist attractions that need to be connected to tourists; transparency in the region can encourage interaction either through wall fences or on the walls of buildings; The setback on private land can be utilized to support the convenience of interaction; car-dependency can inhibit visual and spatial access from the path space to the inner building space limiting the interaction.

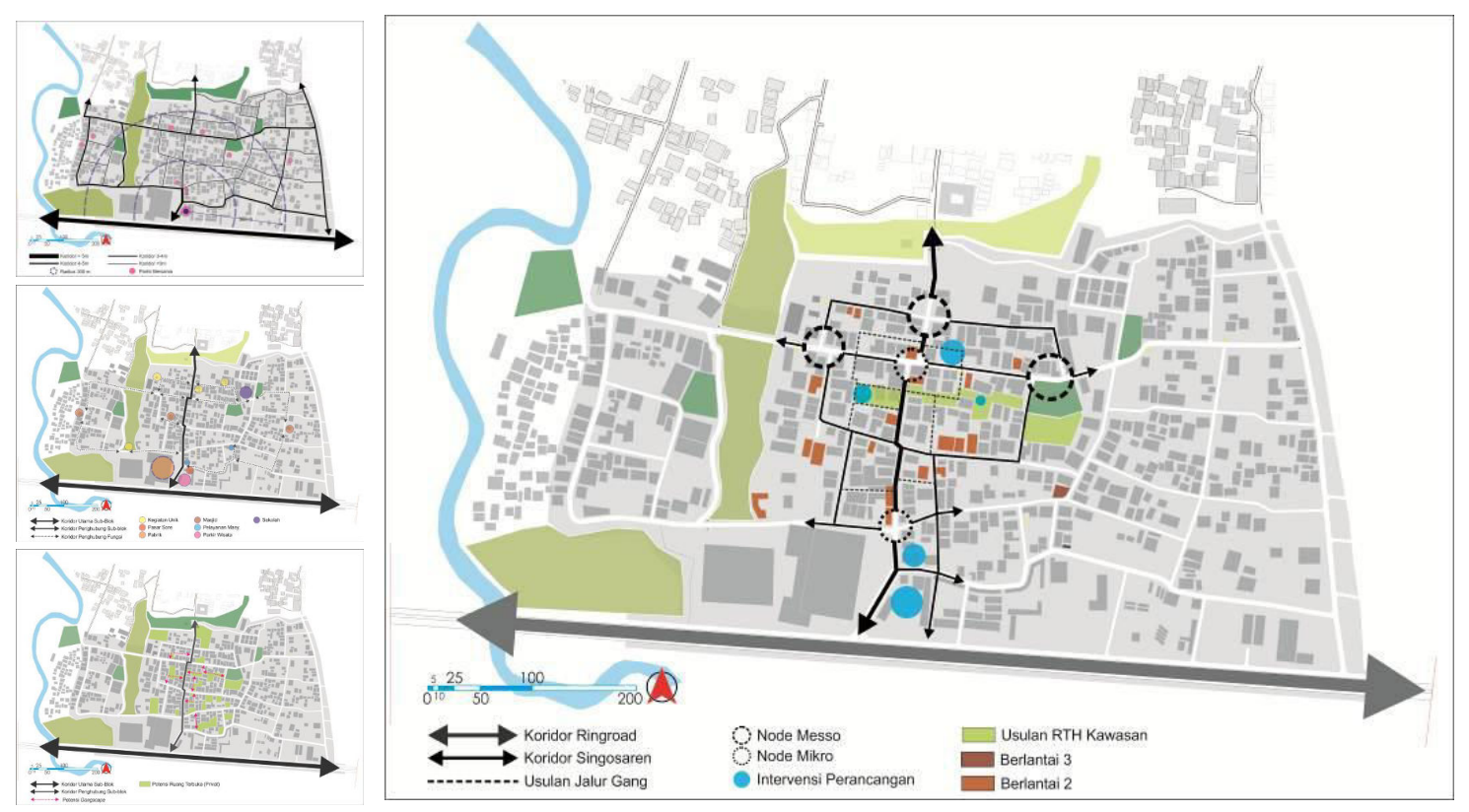

Fig. 21. Mapping of permeability analysis results on Singosaren. 


\section{References}

Bentley, I., Alcock, A., Murrain, P., McGlynn, S., \& Smith, G. (1985). Responsive Environments a Manual For Designers. London: Architectural Press.

Carmona, M., T. H., OC, T., \& S. T. (2010). Public Places Urban Spaces: The Dimension of Urban Design. Oxford: Architectural Press.

Carr, S., Francis, M., Rivlin, L. G., \& Stone, A. M. (1992). Public Space. New York: Cambridge University Press.

Cooper, C., (1993). Tourism: Principles \& Practice. London: Pitman Publishing.

Dovey K. \& Wood, S.,2011, Public/private Interfaces in the Innercity: Types, Adaptations, Assemblages, State of Australian Cities Research Network, viewed 04 May 2017

Dovey, K. \& Symons, F. 2013. Density without intensity and what to do about it: reassembling 